\title{
The Hungarian Reception and Impact of a Multinational Company on the Case of Suzuki in the Town Esztergom
}

\author{
Eva KIss \\ Geographical Research Institute, Hungarian Academy of Sciences, \\ Budapest, Hungary
}

\begin{abstract}
The main purpose of this study is to sum up the Hungarian reception of a multinational company, Suzuki, and its impact on the local economic and social surroundings in the town Esztergom. This research is the first experiment in Hungary to reveal the impact of large investment primarily on the local-social economic surroundings, because during the socialist period researchers have investigated the impact of large investments mainly on the physical environment. This investigation, concluded in 1992, is also important because after 1989, with the increase of the consciousness of responsibility for the geographical surroundings the population reacts more and more actively to technical establishments. By the survey it has become obvious that Suzuki's large investment has been well received and it has had significant effects on the economic and social development of the town Esztergom.
\end{abstract}

Key words: technical investment, economic and social effects

\section{Background and Aim of Investigation}

In international scientific thinking the multidisciplinary analysis of environmental impact began in the 1970s, whilst in Hungary the adaptation of its methods began to spread a little later, from the beginning of the 1980s. It was accelerated by the ministries, which were responsible for the large state investments and required this research. These investigations (Rétvári 1986, 1989; Englader et al. 1987; Slovic 1987; Faragó and Vári 1989; Márföldi et al. 1989; Pethõ, M. and Pethõ, Sz. 1991), however were basically aimed at analysing the probable effects of the site of the planned investment on the environmental and not (or less) on the local economic, social surroundings. The main reason for this could have been that these investments (for example Gabcikovo-Nagymaros Water Barrage, Nuclear Power Station in Paks, Radioactive Waste Cemetery in Ófalu) were planned to be established further from the settlements, in peripheral areas, therefore they have escaped the attention of the population in nearby settlements. The other reason could have been that during the socialist period the population had not been provided with suitable knowledge about their danger and unfavourable con- sequences in the future, because of the censorship of the press. (This meant that then there was no possibility to publish different opinions about, e.g. a factory location, only those which were preferred by the government, which is why we can say that communication channels were one-way and their information was "ordered".)

After the collapse of the socialist system huge changes have also ensued in this field. A freer flow of information has aroused the "sleeping" and still "unconscious" population, thus the more frequent information about the different cases of environmental pollution have caused large tensions and conflicts. With the increase of the consciousness of responsibility for the geographical surroundings, the population begins to react more and more actively to the technical establishments that will be built next to them if those interfere with their interests and/or they are harmful to their health and living conditions. In order to avoid protests or demonstrations or following these, more serious atrocities which may carry unforeseeable consequences, it is necessary to consult with the population living next to the planned large technical establishment, before beginning the construction. Later, during operations, the companies also have to be continually informed 
about public feeling by public opinion research.

Research so far also indicates the spread of this approach, although they have investigated the impact of large investments mainly on the physical environment. This is why the main objective of my investigation was, as a new research aspect, to reveal their effects on the social-economic surroundings in the case of Suzuki. This is the first experiment in our country to describe the reception of a multinational company and its impact on the local economic and social surroundings. The primary purpose of this study is to sum up the results of this research.

Though the Suzuki factory was not considered as dangerous as a nuclear power station, before its establishment it would have been necessary to gather information by a preliminary survey of the opinion of the inhabitants. An investment of the size of Suzuki's is not just a technical issue, but is also connected with the social-economic development of the region, not least in the ways it shapes the lives of local residents. Thus, the opinions and attitudes of the local population should have been considered. Throughout the investment, from preparation to operation. the local population was not consulted, so the survey concluded in 1992 , has made up for this insufficiency. It would have also been necessary to inform the local inhabitants about the impact of a Japanese factory settling down in the area and what they could expect concerning working conditions, discipline at work and salary. This is particularly important in the case of two countries with such radically different work cultures and mentalities since these can cause cultural confrontation.

\section{History and Some Features of Hungarian Suzuki Corporation}

The legal framework for the establishment of firms involving foreign participation has been in place since 1972 but it is only since the introduction of the Act on Economic Association in 1989, which established the legal framework, that the level of foreign investment has increased. Thus most joint ventures were established after the change in Hungary's politi- cal and economic system. Until 1988, 60\% of all foreign capital was in industrial ventures but since that time the number of joint ventures has increased not only in industry but also in other financial sectors (especially in domestic trade). Owing to this, by 1995 , the share of joint ventures in industry was reduced to about $20 \%$, although their number has increased and now it is around 4,000. Hungarian Suzuki Corporation (HSC) is one from the latter group. It is the largest Japanese investment in Hungary and also in East-Europe.

The factory facilities have been set up in the town Esztergom, in the Komárom-Esztergom county. The town is a religious centre, located about $50 \mathrm{~km}$ north of Budapest, on the Danube, close to the Slovakian border with a population of 30,000 (Figures 1 and 2).

Brief history of HSC is as follows:

1985: Suzuki Motor Corporation submitted to Hungarian government a proposal of passenger car production in Hungary.

1990: Basic Agreement was signed.

1991 April: Joint Venture Agreement was signed. HSC was founded as a joint venture company.

1992 October: Production started.

1994 April: Exports started. As It can be seen, the process of negotiations had taken a long time before the investment actually went ahead. The first offer by Suzuki to set up a factory was in 1985 but no agreement was reached until January 1990. Finally the Hungarian Suzuki Corporation was founded on April 24, 1991.

The current shareholders and their rates are as follows: Suzuki Motor Corporation 55.2\%, Holding company established by 65 Hungarian financing/automobile related companies to invest in HSC (Autókonszern) 24.9\%, Itochu Corporation $13.6 \%$, International Finance Corporation (under the organisation of World Bank) $3.5 \%$, Hungarian State (through Hungarian Bank for Investment and Development Ltd.) 2.8\%. In the future, however Hungarian State will probably sell her shares. The investment cost totals, as of today, HUF 14.1 billion, i.e., US $\$ 141$ million. Last year the initial capital of the 


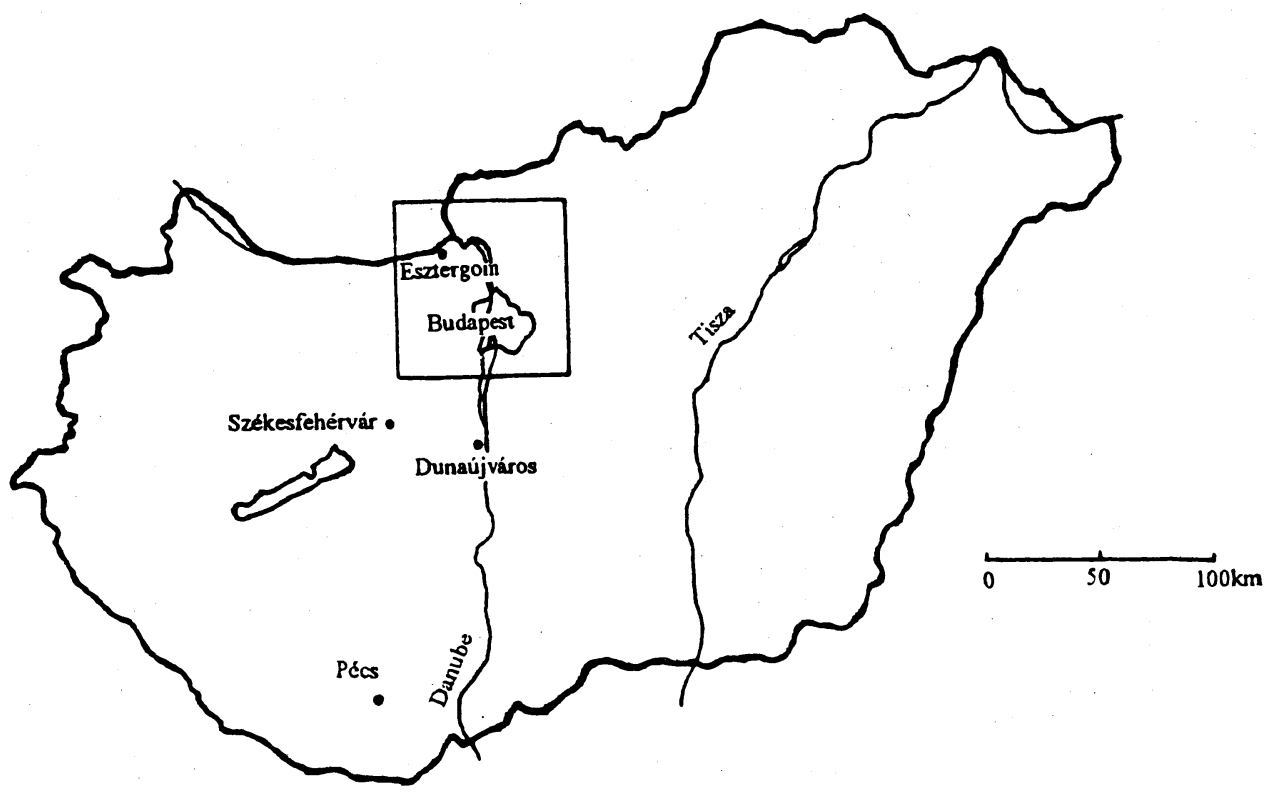

Figure 1. Potential appliers for the Suzuki premises in Hungary.

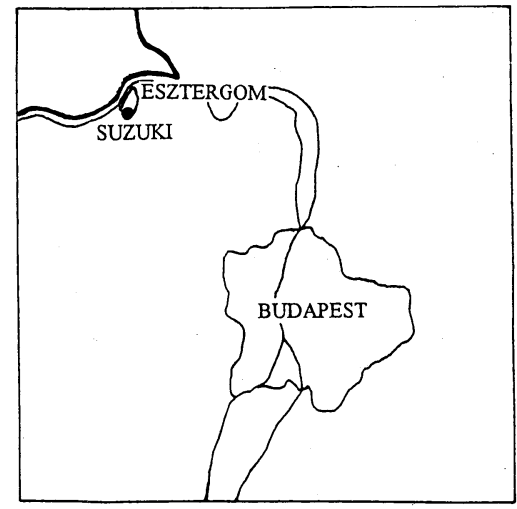

Figure 2. Location of Suzuki in the town Esztergom.

factory was increased by the Japanese and thus their share reached $75 \%$. This was also the reason for replacing the Hungarian director with a Japanese one.

Before the choice of the Hungarian location, there were many negotiations and Suzuki's specialists had considered many factors and finally foreign specialists had decided that Esztergom had the most suitable location among the applicants for the reception of the factory. According to the leaders of the town, the most important factors (the same ones mentioned by the general manager of the factory) in Esztergom's favour were: the presence of the river Danube to be used as an international transport route, the potential for constructing a port on the river,

the close proximity of the town to Budapest.

These viewpoints were decisive in the final decision because the other possible locations (Dunaújváros, Pécs, Székesfehérvár) also possessed these factors (namely an industrial workculture, infrastructure, production traditions, relatively high-skilled work force and potential factory sites free of charge) which Esztergom also had (Figure 1).

The factory is a newly-built unit. In other words this is a "greenfield" investment, which means that the factory was located in an area where there had not been any firms previously. The construction of the car factory, the 28th of the Suzuki Motor Corporation, started on the 30 hectare site in the west part of Esztergom in the autumn of 1990. The company was given 16 hectares free of charge by the local authority whilst the other portion of the land was acquired from the State Property Agency. The total built area is 33,000 square meters on a ground of 350,000 square meters and its overall impression can best be compared to that of the Kosai plant of Suzuki Motor Corporation. 
Production began in October 1992, but the formal opening, following Japanese custom (to celebrate only after having reached the full capacity of the first shift), was held only in May 1993. The production is aimed at both the domestic and the export market. Exports started from April 1994. HSC already achieved 60\% local content in March 1994. In 1992 (Oct. 1992 -March 1993) 3,548 units, in 1993 (April 1993March 1994) 13,583 units were produced. Nowadays about 40,000 cars are produced and the projected annual production capacity is 50,000 units. The current production models are: Swift $1.0 \mathrm{H} / \mathrm{B}$ 5-door M/T, Swift 1.3 H/B 5-door M/T, Swift 1.3 Sedan 4-door $M / T$. In the beginning only the second one was exported, however from the end of 1994 all three types have been exported. The main customers are: the Netherlands, Italy, England, Germany, and China. In 1992916 units, in 199312,556 units were sold in Hungary.

Taken as a whole, Suzuki is a very important investment for Hungary, because, among other things, it enables the introduction of a new industrial branch, car industry, which has not been in the area before, and because it provides workplaces for a declining area with high unemployment.

\section{Methodological Approach}

Data and information for the research project came from a variety of sources. One of them was the different publications and articles regarding the location of the factory. The secord was formed by interviews with local authorities and the general manager of the Suzuki plant. The third, but the most important source, was a survey conducted in 1992 in the town of Esztergom, although the building of the factory had already begun in the autumn of 1990 (Figure 1).

Altogether 1,200 inhabitants of Esztergom were selected for the survey, this being a $4 \%$ representative survey of the town of about 30,000 inhabitants. Out of the 1,200 surveyed, 1,024 were completed; this represents a response rate of $85 \%$ and indicates a very active and successful contribution by the local population. This high response rate was also due to the fact that the survey was carried out with the help of local primary schools. Form-masters of school-classes gave their pupils questionnaires to take home and be filled in by their fathers or mothers (whoever is considered the head of the family). The completed questionnaires were given back to their teacher after a few days, and then sent to the research institute. The questionnaire consisting of 25 questions referring to personal data of the respondents, as well as to their opinions about the factory location, the viewpoints of selection of the work force and to their judgment concerning its probable impact (see Appendix).

During this process, only 895 surveys were considered valid $(87 \%$ of the returned surveys or $75 \%$ of the representative population), but in the case of some questions the valid responses were even less. The incorrect filling in of the questionnaires is the primary reason for this, which may also be traced back to the fact that the possible given answers were not suitable from all aspects or those surveyed could have given unambiguous answers to the questions if certain conditions had been realized. Thus, about $2.7-2.9 \%$ of the local population depending on certain questions took part in the representative survey.

\section{Demographic Characteristics}

Knowledge of the demographic composition of those taking part in the representative survey is indispensable, since it may have fundamentally affected their way of thinking, their opinion and their answers. That is also why it is essential to compare the main features of the respondents to the population as a whole (Tables 1 and 2).

Regarding the heads of the households, the vast majority (81\%) in the survey were between 30-49 years old. One third of the respondents had taken his/her final examination at a secondary school and one fifth had a higher education diploma. The proportion of those who finished vocational schools was $25 \%$. The rather favourable age structure of those surveyed compared to the whole population, can be explained primarily by the fact that their educational level and occupational structure are better. The most plausible reason for 
Table 1. Demographic features of the respondents, Esztergom, 1992

(a) Age

\begin{tabular}{rrrrrrrr}
\hline & Person & $\%$ & & & Person & $\%$ \\
\cline { 1 - 3 } \cline { 5 - 7 } $18-29$ & 28 & 3 & & $60-69$ & 8 & 0.9 \\
$30-39$ & 384 & 43 & & $70+$ & 1 & 0.1 \\
$40-49$ & 344 & 38 & & N/A & 79 & 9 \\
$50-59$ & 51 & 6 & & Total & 895 & 100 \\
\hline
\end{tabular}

(b) Highest educational background

\begin{tabular}{lcc}
\hline & Person & $\%$ \\
\hline Less than 8 years & 2 & 0.2 \\
Primary school (8 years) & 85 & 9 \\
Vocational training school & 223 & 25 \\
Secondary school & 298 & 33 \\
University, high school & 190 & 21 \\
Not available & 97 & 11 \\
Total & 895 & 100 \\
\hline
\end{tabular}

(c) Occupation

\begin{tabular}{lcr}
\hline & Person & \multicolumn{1}{c}{$\%$} \\
\hline Physical worker & 258 & 29 \\
Intellectual worker & 310 & 35 \\
Contractor/entrepreneur & 62 & 7 \\
Pensioner & 33 & 4 \\
Unemployed & 156 & 17 \\
Not available & 76 & 8 \\
Total & 895 & 100 \\
\hline
\end{tabular}

(d) Number of family members

\begin{tabular}{rrrrrcc}
\hline & Person & $\%$ & & & Person & $\%$ \\
\cline { 1 - 3 } \cline { 5 - 6 } & 10 & 1 & & 7 & 6 & 0.6 \\
2 & 60 & 7 & 8 & 1 & 0.1 \\
3 & 161 & 18 & 9 & - & - \\
4 & 422 & 47 & 10 & 1 & 0.1 \\
5 & 160 & 18 & & N/A & 57 & 6 \\
6 & 17 & 2 & Total & 895 & 100 \\
\hline
\end{tabular}

(e) Yers of residence in the town

\begin{tabular}{rrrrrrr}
\hline & Person & $\%$ & & & Person & $\%$ \\
\cline { 6 - 7 } \cline { 5 - 7 } 1 & 13 & 1 & & $31-35$ & 74 & 8 \\
$2-5$ & 46 & 5 & & $36-40$ & 139 & 16 \\
$6-10$ & 93 & 10 & & $41-45$ & 81 & 9 \\
$11-15$ & 148 & 17 & & $46-50$ & 51 & 6 \\
$16-20$ & 73 & 8 & & $51+$ & 14 & 2 \\
$21-25$ & 49 & 5 & & N/A & 51 & 6 \\
$26-30$ & 63 & 7 & & Total & 895 & 100 \\
\hline
\end{tabular}

Source: The author's survey.
Table 2. Demographic features of the population, Esztergom, 1990

(a) Age

\begin{tabular}{|c|c|c|c|c|c|}
\hline & Person & $\%$ & & Person & $\%$ \\
\hline $0-14$ & 6,194 & 21 & $60+$ & 5,105 & 17 \\
\hline $15-39$ & 11,055 & 37 & Total & 29,841 & 100 \\
\hline $40-59$ & 7,487 & 25 & & & \\
\hline
\end{tabular}

(b) Highest educational background

\begin{tabular}{lrr}
\hline & Person & \multicolumn{1}{c}{$\%$} \\
\hline Less than 8 years & 608 & 2 \\
Primary school (8 years) & 8,691 & 32 \\
Vocational training school & 3,628 & 13 \\
Secondary school & 5,367 & 19 \\
University, high school $_{\text {Total }^{\text {a }}}$ & 2,656 & 10 \\
\hline
\end{tabular}

(c) Occupation

\begin{tabular}{lrc} 
& Person & $\%$ \\
\hline Physical worker & 7,665 & 26 \\
Intellectual worker & 4,909 & 16 \\
Contractor/entrepreneur. & 58 & 0.2 \\
Pensioner & 6,727 & 22 \\
Unemployed & 379 & 1 \\
Total & 29,841 & 100 \\
\hline a Includes primary students (24\%). & \\
b Includes dependants (35\%). & \\
Source: Census data of Komárom-Esztergom County, \\
1990.
\end{tabular}

the discrepancy is that pupils of the local primary schools were used to help distribute the survey forms to their parents who were likely to be in a younger than average age cohort. It is well-known that the younger generations generally have higher levels of education and better qualifications than the older. They are usually more economically active and healthier. In consequence of the higher educational level there are many intellectual workers, for example: teachers (16\%), engineers (12\%), managers (6\%), among the respondents. The greatest numbers of physical workers were mechanics $(11 \%)$, drivers $(9 \%)$, electricians $(9 \%)$, decorators $(7 \%)$ and motor mechanics $(5 \%)$. The higher rate of the entrepreneurs (7\%) and the lower rate of the pensioners $(4 \%)$ compared to the whole population is also due to the younger age-structure.

All respondents live in Esztergom. More than $90 \%$ have lived in the town for more than 5 
years and only $6 \%$ had moved to the town in the last five years. The distribution of the respondents was relatively equal throughout the town, although there were some parts in the east and in the west and southwest part of the town, nearer to the Suzuki factory, as well as in the middle of the town, where the larger proportion of those taking part in the survey were concentrated. As will presently become apparent from the forthcoming, in some cases the place of the residence might play a very important role in the quality of the answer.

\section{The Experiences of the Respondents}

The main proof of the population's knowledge is that although there had been no formal attempt to inform residents about the planned investment, half of the respondents, generally the more educated living in the west of the town close to Suzuki's plant, knew about the plans some years before their realization. Some $39 \%$ only heard about Suzuki's project once it had begun. In total, $83 \%$ of the respondents supported the investment project with only $4 \%$ opposing it (mainly entrepreneurs and the unemployed, those who could have gained most from the plant's construction). Those firmly opposed lived in the part of town close to the factory and this might be an explanation for their negative answer. Fifty-two per cent of those who supported the Suzuki investment were aged under $40,60 \%$ had secondary and/or higher education, and $81 \%$ had lived in the town for more than 10 years.

This large volume of support regarding the factory-location was also to be expected on the basis of newspaper articles of that time. The smallest uncertainty filled the inhabitants of the town with anxiety when they heard that Suzuki had other potential locations with better infrastructure and cheaper costs. These and other similar presentations in the press also helped to increase the level of local support in Esztergom and this is why only $4 \%$ of the survey respondents indicated that they had heard of dissatisfaction with the presence of Suzuki in the plant, but such views were not significant as they were not mentioned in the newspapers.
Forty-nine per cent of the respondents thought that Esztergom was chosen only for one reason; because it was proven the most favourable solution from an economic point of view. At the same time one fourth could not give a reason why their residence was chosen, whilst 5\% mentioned other location criteria: like the favourable geographical location of the settlement, the good transport network, the need to ease unemployment and other subjective factors. Some special reasons were also noted, such as the fact that Esztergom as a settlement is similar to the settlement of Suzuki's headquarters in Japan, and that Esztergom's fame as a religious centre would make a good advertisement. Someone also mentioned that the Japanese consider Esztergom an excellent bridgehead from where it would be much easier to supply the European market and to have an influence on the European car market dominated by Germans, which was the reason for choosing it as a location.

The interviews with one of the local officials also confirmed that the explanation of those (12\%) who thought that Esztergom had been selected because the town had offered the most advantages to the factory, was incorrect. In reality, not the town but the national government gave Suzuki various types of support from central funds aimed at stimulating investment, employment and commercial advantages. The government also extended the provision of a ten year tax exemption. Thus the role of the local authority was not significant.

Some $80 \%$ of those who completed the survey stated that the location of Suzuki's plant would not have an unfavourable impact on their residence, however most of them lived some distance away from the site. Those most concerned with the impact of the plant were between 30-39 years old mainly with one or two children, one third had taken their final school examination, one fifth were skilled workers and the same proportion had a higher educational diploma. Two-thirds were physical workers living in the west of the town close to the site. The largest percentage insisted that environmental pollution would grow because dust, noise and traffic congestion would increase in consequence of the building of the 
factory, and maybe later, of the production in the settlement. This also would have an effect on the health status of the local population and perhaps the number of patients suffering from cancer would also increase. Others felt it was inappropriate to have a large manufacturing facility in a cathedral town dependent on attracting tourists. Some respondents were afraid of a growing number of immigrants into the town.

During construction, many people (43\%) experienced the betterment of work possibilities. According to $23 \%$, the supply of public utilities (water, telephone, etc.) changed favourably and $10 \%$ opined that the road and transport conditions improved. Simultaneously several negative consequences were observed after construction began; increased complaints of dust and noise pollution and road surface problems owing to overuse by heavy lorries. At the same time the respondents did not yet attribute such an unfavourable impact to the operating factory, because few people answered "yes" to the question "Will the factory have any unfavourable influence on your residence?"

According to the survey, the inhabitants expected two things from the location of Suzuki's plant in Esztergom: the creation of many new jobs and that it would support the development of the town. The former expectation continues to be met as Suzuki is still recruiting workers, but the latter has not because the company has not made funds available to develop the town. In one local leader's opinion, the main reason for this is that Suzuki has been affected by the recession in the Hungarian and world economy and has not been operating for very long. His conviction is that if the company had started operating earlier, Suzuki would have been in a position to contribute to the development of the town. The inhabitants hope and trust that this will be the case in the future, especially if the top management of the factory live in the town, because then they will feel much more the unfavourable infrastructural conditions and other negative factors, thus they will feel much more the urgency to develop the town.

Several respondents also hoped that the wages would be higher, that the price of cars would fall, that the factory would support sport, culture, town-planning and that the company would provide the social tasks that were previously provided by state factories. However, by now it has become obvious that these expectations will be remain hopes, because the financial situation of the plant means that it is unable to meet these demands. Suzuki is still having loss and according to the forecast, favourable changes can be expected only from the following year on. The realisation that Suzuki's presence will not have such beneficial effects has resulted in pained and bitter inhabitants. The enthusiasm and euphoria which surrounded the decision by Suzuki to locate in Esztergom have slipped away.

Owing to being familiar with the local situation most of the inhabitants could correctly define the requirements for selecting employees on the questionnaires. According to $30 \%$ of the respondents, age, qualifications and English language skills were the main criteria. The first two were important in the case of production workers, whilst the latter was for white-collar workers. Initially the company indicated that only candidates aged 25 years or less would be considered, but a year later this requirement was relaxed to 32 years, because there were not enough applicants. The average age was 28.2 years. The view by the Japanese management was that the young can better adapt to the Japanese style, conditions and methods of work and work hard; they are more flexible and healthier and are not tainted by socialist attitudes to work and the working culture.

Besides local inhabitants, the factory accepted applicants living within $25-30 \mathrm{~km}$ of the plant. According to local authority's officials and managers of the factory, the place of residence of candidates plays only a secondary role in the selection procedure. In other words, living in Esztergom was not necessarily an advantage. However, according to $40 \%$ of the respondents this is not true, as they believed that the factory discriminated in favour of applicants from the town against those from the surrounding area. The background of this is that Suzuki, as with other companies, strives (because of economic, financial circumstances) to have the majority of workers from the local applicants since they do not have to be paid for 
transport costs. Suzuki also tries to minimise the cost of transport by using their own buses to carry workers to and from work. It is also very important, because the shift pattern at Suzuki differs from the standard one (in Hungarian factories shifts generally last 8 hours, from $6: 00$ to $14: 00$ ). At Suzuki it is from $7: 00$ to $15: 50$, including half an hour lunch time and breaks.

Only $7 \%$ of the heads of families had applied for a job at Suzuki, although none had been successful. The majority of the applicants were young (30-39 years old) skilled manual workers with one or two children, living in the east part of the town far away from the factory. The number of applicants was much less from the near part of the town close to the factory, which is rather strange. Only $4 \%$ of those who had not applied yet, planned to do so in the future and $14 \%$ of them had not decided yet whether they would apply for a job at Suzuki or not. It is quite surprising and thought-provoking, that only a small number of people have thought about working for such a world renowned company as Suzuki. The most likely reason for this is that three quarters of the respondents already have good reliable jobs which they do not intend to give up.

However, what is the retarding force which causes even the unemployed not try to obtain work at the Suzuki plant? Only $13 \%$ of the unemployed had applied for a job at the Japanese firm and only 8\% indicated that they might try to apply for a job at this factory in the future, albeit according to $80 \%$ of the respondents, the job possibilities in the town are very low. One of the possible reasons for this is that at the time of the survey there were some (probably exaggerated) press reports about the training of Hungarian workers in Japan and these did not have an attractive influence at all. According to the unfavourable news Hungarians had to work overtime without overtime wages, they did not get enough food and Hungarian dishes, the intensity of work was greater and the workshop discipline was stricter than they were accustomed to at home. These experiences (or exaggerated rumours) caused shock among workers with average abilities used to a socialist workshop discipline, because they did not know the expectations of Japanese managers and a Japanese company with another kind of work culture and traditions, and therefore had a considerable impact. The result was that the relationship between the inhabitants and firm worsened. The attraction of the great name had spectacularly waned. People were afraid of applying for a job at Suzuki.

Another possible reason is that the unemployed, hearing about the expectations of the Japanese management, realised they were unsuited to working for the company. Some of them are so, because they had problems at former state owned factories or because they were not hard workers or were in bad health. Others who were older or less skilled, could not apply even if they wanted to, although most would take on the retraining. Mainly in the beginning, the low wages also could have been the reason for some of the unemployed not applying for a job at Suzuki, because it was thought that the combination of unemployment benefit (net US $\$ 100$ per month) and "black work" could provide a higher income. This inspired the belief that it would not be worth working for Suzuki, as the requirements would be high, but the salaries relatively low. In 1992-1993 the wages were net US $\$ 180-200$ per month.

Those people who accepted Suzuki's low pay did so out of necessity, because they could no longer get unemployment benefit and/or because alternative sources of work in the town were limited as at that time almost all the state firms had been closed down and new firms had not yet been established. Thus Suzuki was the only significant employer with its 700 workers in Esztergom and it had a monopolistic position in the labour market since it was the only large firm which offered jobs to the local workers, therefore it was able to dictate terms and conditions.

In spite of these unfavourable conditions, at the time of the survey more than $50 \%$ of the inhabitants were partly satisfied with their residence, whilst almost $25 \%$ of them were not at all. The former mainly lived in the centre of the town, whilst the latter primarily in the west part of the town. There was no relevant difference between the members of the two groups 
concerning age and educational level. In spite of the large dissatisfaction with their residence, $85 \%$ of the respondents did not intend to move which means that besides job opportunities other factors were also important in the choice of residence. Those who planned to move were less than 40years old, mainly manual skilled workers and had been living for more than 10 years in the town.

\section{Recent Employment and Working Condi- tions}

It is worth mentioning recent employment and working conditions, because many things have already changed since the time of the survey. In the beginning Suzuki had about 700 employees, but nowadays it has more than 1,200 employees. One sixth of them are women, whose number has greatly increased in recent years. Earlier, Suzuki did not employ women in production at all, only in administration. Lately it had become necessary again to extend the agelimit upward, which means that now the maximum age is 45 years for a physical worker, who wants to apply for a job at Suzuki. Thus, the average age is around 35 years.

Besides the Hungarians there are also about 40-50 Japanese employees dispatched from SMC Japan to transfer Japanese technology. By 1994 a special hostel had been built for them on the outskirts of the town. Up to now, 220 staff have been dispatched from HSC to SMC Japan to study technology, quality control etc. Today however only the best Hungarian workers can travel to Japan as a reward.

The largest proportion (87\%) of the employees are physical workers and only $13 \%$ of them are intellectual workers. According to a leader of the factory, nowadays the fluctuation of workers has been reduced to a few per cent. Today it is not significant, although some years ago it was much higher, more than $10 \%$.

Recently about 400 workers (one third of all workers) of Suzuki live in Esztergom and 800 in its surroundings, within $50 \mathrm{~km}$ of the plant. Most of the top leaders of the factory still commute daily since they live mainly in the capital of Hungary, Budapest, which is a good hour's distance by car from Esztergom. Earlier, after the collapse of state companies, when the unemployment rate was rather high, around $17-19 \%$, more local workers (living in the town) were employed and there were fewer commuters, but this has changed. The reason is that in the past one or two years some new firms settled down in the town. This means that, on the one hand, work possibilities got better and the unemployment rate decreased to $11-12 \%$, while on the other hand today Suzuki already has some rivals on the labour market.

The amount of salary (net) has increased to about US\$ 250-300 per month for a physical worker. (This exceeds the national average, which is about US\$200-250.) The salary of intellectual workers is higher than this, but there was no exact information available.

According to the general manager of Suzuki, the requirements for workers and working conditions have not greatly changed, but, by today, the relationship between the inhabitants and Suzuki has already changed significantly. The issues have already cooled, and nowadays most of the employees accept Japanese workshop discipline, the speed of work and the expectation of company loyalty. From November 1994, Suzuki has two shifts, both from $7: 00$ to $15: 50$ in order to be able to produce 40,000 units yearly. In the future (maybe from 1997) the factory will need about 100 workers more if it intends to produce 50,000 units a year.

\section{Conclusions}

Suzuki's large investment has been well received, but a number of problems have surfaced, most of which could probably have been prevented if the inhabitants had had more information about the Japanese style of work and what had been expected in terms of the investment's impact on the socio-economic development of the town. The sources of problems could have been found early, if a survey about the reception of a factory location had been conducted among the population before the beginning of construction.

Parallel with the building and operating of the factory, favourable and unfavourable impacts alike can be observed in the urban landscape, in the infrastructure and in the quality of 
the environment. Even the popularity and reputation of the town grew, which advantageously affected local tourism and maybe it promotes the establishing of other famous companies in the future.

Especially in the beginning, the Suzuki factory was a determinative power in the local economy as it gave work to hundreds of people. Nowadays its regional role has grown. It urged not only the development of local small firms and private enterprises, but also those in other parts of the country, because it provided them with possibilities for delivery and subcontract work. Thus the economic influence and qualitative requirement system of the factory have reached different points of the country.

The changes in the local economy do not leave the local social surroundings and the mentality of people untouched either. More and more attention is focused on acquainting people with Japan and Japanese culture and on teaching Japanese language at the local primary and secondary schools in Esztergom. Nowadays the demands of Suzuki determine firmly what kind of skilled workers are trained at the local vocational schools. As the top managers of the factory are still commuting. they have not taken part in the local community activities and affairs, although it would have advantageous effects on the town's development if their residences were in Esztergom.

On the whole, the investigation has proved that a large investment like Suzuki may play a very important role in the social and economic development of the settlement.

(Received Aug. 28, 1995)

(Accepted Dec. 16, 1995)

\section{Appendix: Survey Questions and Answers}

1. When did you first hear about the location of Suzuki factory in Esztergom?
a) several years ago
b) about 2 years ago
$48 \%$
c) about a year ago
39
d) did not know
3

2. Do you agree with the location of Suzuki factory in the town?
a) yes
b) no
$83 \%$
c) do not know
8

3. Have you heard of any dissatisfaction because of the construction of the factory?
a) yes
b) no
$4 \%$
c) do not know
68
23

4. Why do you think Esztergom was chosen by the specialists?
a) from economic reasons, it was the most favourable
b) Esztergom offered the
Suzuki the most advantages $\quad 12$
c) do not know 25
d) other reasons
12
25
5

$49 \%$

5. Will the factory have any unfavourable effect on your residence?
a) yes
$13 \%$
b) no
79

6. What kind of changes have you experienced owing to the construction of the factory ?
a) work possibilities improved
$21 \%$
b) road infrastructure improved
c) public utilities (water, canal, telephone) improved
5
d) prices of flats and building
sites rose
4.6
e) public security worsened
2
f) dust and noise pollution increased due to increasing transportation
g) heavy lorries damaged
the road surfaces
h) other
8

7. What do you expect from the factory after the beginning of the production?
a) many new jobs
$19 \%$
b) promotion of the development of the town 16
c) the town will get one part of tax paid by the factory
d) other
3

8. What are the criteria for selecting employees of the factory?
a) $\operatorname{sex}$
b) age
-
$\mathrm{b}+\mathrm{c}+\mathrm{e}) \quad 30 \%$
c) qualification 1.2
$\mathrm{b}+\mathrm{c}) \quad 9$
d) residence -
b+c + d) 7
e) knowledge of English
f) no criteria 0.8

9. Is there any discrimination in employment between candidates from the town and from the surroundings?
a) yes
$40 \%$
b) no
23
c) do not know
32

10. Have you applied for a job at Suzuki ?
a) yes
b) no

11. If you applied, was it successful ?
a) yes
b) no 
c) do not know

12. If you have not applied yet, do you plan it in the near future?
a) yes
$4 \%$
b) no
69
c) do not know
14

13. What are the employment possibilities like in the town?
a) good $2 \%$
b) medium
c) bad
78

The missing per cent means the invalid responses. The data in Question 6 indicate the share of those who have chosen only one response of all. (Plural choice was also possible.)

\section{References}

Englader, T., Faragó, K., Slovic, P., and Fischhoff, B. 1987. Risk observation in the USA and in Hungary. Pszichológia 4: 469-482. (HE)

Faragó, K., and Vári, A. 1989. Opinions about the location of the first Hungarian dangerous refuse burner. Szocioiógia 1: 95-106. (HE)

Márföldi, G.. Rétvári. L., and Nikodémus, A. 1989. A Nagymarosi Gát létesitésének földfizikai problematikája és a komplex megfigyelõrendszer (Geophysical problems of the establishment of the Nagymarosi Barrage and the complex observational system). Mûhely $5 .(\mathrm{H})$

Pethõ, M., and Pethõ, Sz. 1991. National experiences about utilisation and shooting of dangerous wastes. Magyar Tudomány 5: 579-582. (HE)

Rétvári, L. 1986. A Dunántúli-középhegység bányászati tevékenységébõl származó társadalmigazdasági hatások elemzése és értékelése (Analysis and evaluation of the social and economic impacts coming from mining activity in the Transdanubian mountains). Manuscript. (H)

Rétvári, L. 1989. A Paksi Atomerõmû komplex környezeti hatásvizsgálata (Complex environmental influence investigation of Nuclear Power Station in Paks). Manuscript. (H)

Slovic, P. 1987. Risk observation. Pszichoiógia 4: 455468. (HE) 